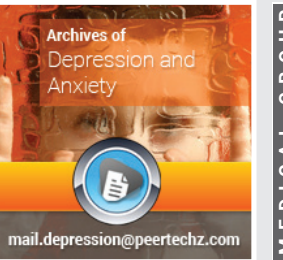

\title{
Translational research of antidepressants with an example of cannabidiol effects
}

\section{Alexandra Šulcová*}

Professor of Pharmacology, Scientific Board of the ICCI, Department of Pharmacology, Masaryk

University, Brno, Czech Republic

Received: 05 October, 2020

Accepted: 18 November, 2020

Published: 19 November, 2020

*Corresponding author: Alexandra Šulcová, Professor of Pharmacology, Scientific Board of the ICCI, Department of Pharmacology, Masaryk University, Brno, Czech Republic, Czech Republic, Tel: 420732167 6789; E-mail: sulcova@med.muni.cz

ORCID: https://ORCID/0000-0001-8854-558X

Keywords: Translation research; Depression; Animal models; Endocannabinoid system; Cannabidiol

https://www. peertechz.com

Check for updates

\section{Summary}

Despite that not all symptoms of depression can be achieved in animals the translational animal models can mimic the aspects of human depressive disorders in terms of disease symptoms as well as their neurobiological mechanisms. Results of testing the antidepressant drug effects in behavioral animal models of depression are presented. In these models, depressive-like behavior is induced by various stress factors in laboratory animals. However, patients suffering from the Therapeutic Resistant Depression (TRD) do not have high-stress markers. Thus, animals with predisposing factors leading to heightened stress responsiveness as a tool for discovering drugs for human TRD treatment are also presented. Antidepressant treatment effects are reported to be achieved through complex influences on body responses associated to reward, stress, and inflammation, the processes reported to be influenced by activities of the Endocannabinoid System. Cannabidol (the cannabinoid without abuse potential) is reported as an antidepressant agent.

\section{Introduction to translational research on depression}

According to the definition of the "European Society for Translational Medicine (EUSTM)", translational medical research is defined as an interdisciplinary branch of the biomedical field supported by three main pillars: benchside, bedside, community [1].

The translational medical research relies on the principles of transformation of the basic research results into clinical medical practice. The phenotype of human disease is modeled in laboratory animals by identifying candidates for biomarkers enabling testing of pathways and networks, which could then be validated in clinical practice, even for the choice of appropriate treatment. In the case of preclinical studies on depressive disorders, it has to be admitting that despite that not all symptoms of depression can be achieved in animals the animal models used are still essential not only for testing and validating the effects of new drugs with potential antidepressant activity but also for improvement of our knowledge on neurobiology of this psychiatric disorder.

Symptoms of depressive disorders in man (- persistent feelings of sadness, hopelessness, worthlessness, or emptiness; irritability, frustration or restlessness; - loss of interest in activities or hobbies that used to be enjoyable; - difficulty sleeping, sleep disturbances, or sleeping too much; - fatigue and lack of energy; difficult thinking, remembering, concentrating, or making decisions; - appetite or weight changes; - recurrent thoughts of death or suicide; - physical symptoms such as headaches, stomach aches, or back pain) are associated with behavioral changes. Thus for investigating antidepressant drug effects in rodent behavioral tests attention has to be paid to disinhibition of behavior suppressed by some means (often induced by stress) that can be monitored objectively while into account has to be taken specific endophenotypic behavioral variations [2]. However, the animal models of depression should correlate as much as possible with all other changes observed in depressed patients: a) maladaptation with increased irritability; b) neurochemical changes: disorders of aminergic neurotransmission; c) neuroendocrine disorders: elevated adrenal steroid levels; d) immune deficits. Although not all symptoms of human depression can be achieved in animals, the translational animal models of depression used are still useful to find new drugs with potential antidepressant activity and also to improve our knowledge on the neurobiology of this psychiatric disorder [27]. 


\section{Animal models of depression}

Historically, the following behavioral animal models of depression have been the most recommended:

1) "Mother-Infant Separation in rhesus monkeys" [8,9];

2) "Partner off Spoiling in monkeys" [9];

3) "Learned Helplessness in dogs or rats" who fail to escape inescapable electric shocks in a the situation when escape is possible (Maier and Seligman 1976);

4) "Forced Swim Test"; behavioral despair rats and mice; immobility is reduced by antidepressants [10];

5) "Tail Suspension Test" in mice; antidepressants reduce the duration of immobility [11];

6) "Repeated social defeat" in mice; antidepressants decrease signs of despair [4];

7) "Bilateral Olfactory Bulbectomy (OBX)" in rats or mice causing in animals behavioral, immune and aminergic neurotransmitter functioning alterations which correlate well with changes in depressed patients [1214]. E.G. in our laboratory, we have proven that olfactory bulbectomized rats had: a) lower basal levels of DA and 5 HT and their metabolites [15]; b) increased levels of GABA and glutamate; lower basal levels of DA and 5 HT plus their metabolites; increased levels of GABA and glutamate; higher intravenous self-administration of methamphetamine ); c) reduced levels of endocannabinoids [16].

\section{Endocannabinoid system and depression}

The results of both preclinical and clinical studies on depression indicate insufficient neuromodulatory functions of the endocannabinoid system, and therefore attention is focused on the possible antidepressive effects of cannabinergic therapies [17-26].

The attention is often paid especially to assessing the possible antidepressant effects of cannabidiol CBD, the second major component in cannabis without the abuse potential $[25,27-31]$.

\section{Cannabidiol antidepressant potential}

In our laboratory, we have registered improving effects of $\mathrm{CBD}$ on the alterations which are reported to be induced in the rat model of depression by Bilateral Olfactory Bulbectomy: a) hyperactivity in the Open field test (Klein \& Brown, 1969); b) immune changes [13]; c) aminergic hormonal changes (Cairncross,1977). In our laboratory CBD treatment $(5 \mathrm{mg} / \mathrm{kg} /$ day, orally for 15 days) decreased both the hyperactivity of bulbectomized rats in the open field test and the suppression of the phagocyting activity of their leukocytes and also showed antidepressant-like effects in our ethopharmacological mouse behavioral model of depression: "Repeated Social Defeat in mice.
The number of scientific reports on possible CBD antidepressant effects was gradually increasing [17,20,32-38]. We have proven that in the rat model of depression our olfactory bulbectomized rats had: 1): reduced levels of endocannabinoids [16];

2): a) lower basal levels of DA and $5 \mathrm{HT}$ and their metabolites; b) increased levels of GABA and glutamate; c) showed higher intravenous self-administration of methamphetamine . CBD was also reported to facilitate neurogenesis what helps to attenuate besides psychotic-like and anxiety-like behaviors also depressive-like behavior [39].

In the cross-sectional Clinical Study on cannabidiol in human users [40] almost $62 \%$ of participants reported CBD using as a specific therapy for depression, anxiety, pain, and sleep disorders. A promising therapeutic profile for cannabidiol as an antidepressant drug brought reports of its influence on cellular and molecular changes in brain regions related to the neurobiology of depression: a) increases in levels of BDNF (="peripheral biomarkers" of the Therapeutic Resistant Depression - [41,42]; b) increased synaptogenesis in the medial prefrontal cortex with increases of neurogenesis in the hippocampus [24].

Reviews recently available presenting the therapeutic potential of cannabidiol state the following possible indications: anxiety disorders, post-traumatic stress disorder, autism spectrum disorders, epilepsy, psychotic disorders, Parkinson disease, Alzheimer disease; and depression [21,23,43-45].

\section{Animal models and potential treatment of Therapeutic Resistant Depression (TRD)}

Not all signs and symptoms of depression in man respond to the antidepressant treatments. About $60 \%$ of patients with Major Depressive Disorder (MDD) do not respond sufficiently to the initial antidepressant treatment. Such condition is described in clinical psychiatry as the Treatment-Resistant Depression (TRD)

The diagnosis, epidemiology, and underlying biological mechanisms, as well as new treatment modalities for TRD, were for instance the topics of the "International Thematic Meeting of the College of Neuropsychopharmacology (CINP)" held in Prague, the Czech Republic in 2017. The main topics discussed (understanding the mechanisms underlying the pathophysiology of human TRD and also finding translational animal models that could mimic the whole pathological complexity of TRD) might be a key to identifying new therapeutic approaches $[46,47]$.

The animals defined to be suitable for TRD modeling in preclinical translational research should show increased sensitivity to stress; resistance to chronic treatment with conventional antidepressants; good response to novel modes of antidepressant treatment, e.g. ketamine and deep brain stimulation. As the most promising models are mentioned: a) Rat strain Wistar-Kyoto (WKY); b) Congenital learned helplessness (cLH) rat strain; c) High anxiety behavior (HAB) mouse strain; d) OCT2 ("Organic Cation Transporter 
for NE; 5-HT") null mutant mouse strains e) CB1 receptor knockout mice [5,6,48-50]. Repetitive high-frequency transcranial magnetic stimulation reversed depressive-like behavior and protein expression at hippocampal synapses in chronic unpredictable stress-treated WKY rats by enhancing Endocannabinoid Signaling [51-53], and cannabinoid cannabidiol elicited antidepressant-like effects in both sexes of Wistar-Kyoto rats [54-59].

\section{Summary}

The presented behavioral animal models of human depression prove their importance in searching for effective antidepressants. For fully successful translational research of the pathophysiology and treatment of human depressions (including TRD), it will be important (if technical options are available) to focus, already in the preclinical phase, not only on behavioral markers but also on identificationg possible dysfunctions or lesions of brain structures and their correlation with clinical findings in patients with these types of disorders

\section{References}

1. Cohrs RJ, Martin T, Ghahramani P, Bidaut L, Higgins PJ, et al. (2014) Translational Medicine definition by the European Society for Translational Medicine. New Horizons in Translational Medicine 2: 86-88. Link: https://bit.ly/3pHOPPt

2. Steinberg H (1990) Rodent behaviour tests and antidepressant activity. In Antidepressants: Thirty years On, Leonard B. and Spencer P. (eds.), CNS (Clinical Neuroscience) Publishers, London 508-516.

3. Troisi A (1994) The relevance of ethology for animal models of psychiatric disorders: a clinical perspective. In: Cooper SJ, Hendrie CA (eds) Ethology and psychopharmacology. Wiley, London 329-340.

4. Mitchel PJ (1994) Prediction of antidepressant activity from ethological analysis of agonistic behavior in rats. In: Ethology and Psychopharmacology, S.J. Cooper and C. Hendrie (eds.), J. Wiley and Sons, Ltd., Chichester 85-109.

5. Willner P (1997) Validity, reliability and utility of the chronic mild stress model of depression: A 10-year review and evaluation. Psychopharmacology, 134 319-329. Link: https://bit.ly/3fe6Z4P

6. Planchez B, Surget A, Belzung C (2019) Animal models of major depression: drawbacks and challenges. Journal of Neural Transmission 126: 1383-1408. Link: https://bit.ly/2II84pl

7. Gururajan A, Reif A, Cryan JF, Slatery DA (2019) The future of rodent models in depression research. Nat Rev Neurosci 20: 686-701. Link: https://bit.ly/3pGyloK

8. Harlow HF, Zimmerman RR (1959) Affectional Response in the Infant Monkey. Science 130: 421-432. Link: https://bit.ly/3IFttxQ

9. Lewis JK, Mckinney WT, Young LD, Kraemer GW (1976) MotherInfant Separation in Rhesus Monkeys as a Model of Human Depression: A Reconsideration. Arch Gen Psychiatry 33: 699-705. Link: https://bit.ly/3nvZ1GW

10. Porsolt RD, Le Pichon M, Jalfre M (1977) Depression: a new animal model sensitive to antidepressant treatments. Nature 66: 730-732. Link: https://bit.ly/3kJMXQH

11. Steru I, Chermat R, Thierry B, Simon P (1985) The Tail Suspension Test: A New Method for Screening Antidepressants in Mice. Psychopharmacology 85: 367 370. Link: https://bit.ly/2I05qP6

12. Kelly JP, Wrynn AS, Leonard BE (1984) The Olfactory Bulbectomized Rat as a Model of Depression. Pharmacol Pharm 36: 561-569. Link: https://bit.ly/2IGzk85
13. Song C, Leonard BE (1995) The effect of olfactory bulbectomy in the rat, alone or in combination with antidepressants and endogenous factors, on immune function. Human Psychopharmacology: Clinical Experimental 10: 7-18. Link: https://bit.ly/3IKILCH

14. Kelly JP, Wrynn AS, Leonard BE (1997) The olfactory bulbectomized rat as a model of depression: An update. Pharmacol Ther 74: 299-316. Link: https://bit.ly/3kNmnWK

15. Ruda-Kucerova J, Amchova $P$, Havlickova $T$, Jerabek $P$, Babinska $Z$, et al (2015) Reward related neurotransmitter changes in a model of depression An in vivo microdialysis study. World J Biol Psychiatry 16: 521-535. Link: https://bit.ly/2HkRoE0

16. Micale V, Tabiova K, Kucerova J, Drago F (2015) Role of the Endocannabinoid System in Depression: from Preclinical to Clinical Evidence. In: (c) Springer Science+Business Media New York 2015. Campolongo, L. Fattore (eds.) Cannabinoids and Modulation of Emotion, Memory, and Motivation 97-129. Link: https://bit.ly/35Jym3l

17. Vinod KY, Hungund BL (2006) Role of the endocannabinoid system in depression and suicide. Trends Pharmacol Sci 27: 539-545. Link: https://bit.ly/3kHleif

18. Mangieri RA, Piomelli D (2007) Enhancement of endocannabinoid signaling and the pharmacotherapy of depression. Pharmacol Res 56: 360-366. Link: https://bit.ly/35JAiJm

19. Gaetani S, Dipasquale P, Romano A, Righetti I, Cassano T, et al. (2009) The endocannabinoid system as a target for novel anxiolytic and antidepressant drugs. Int Rev Neurobiol 85: 57-72. Link: https://bit.ly/373JBTZ

20. Resstel LB, Tavares RF, Lisboa SF, Joca SR, Corrêa FM, et al. (2009) 5-HT1A receptors are involved in the cannabidiol-induced attenuation of behavioural and cardiovascular responses to acute restraint stress in rats. $\mathrm{Br} \mathrm{J}$ Pharmaco 156: 181-188. Link: https://bit.ly/35FRr6C

21. Crippa J, Guimarães FS, Campos AC, Zuardi AW (2018) Translational Investigation of the Therapeutic Potential of Cannabidiol (CBD): Toward a New Age. Front Immunol 9. Link: https://bit.ly/396JNo7

22. Stampanoni Bassi M, Gilio I, Maffei P, Dolcetti E, Bruno A, et al. (2018) Exploiting the Multifaceted Effects of Cannabinoids on Mood to Boost Their Therapeutic Use Against Anxiety and Depression. Front Mol Neurosci 11: 424 Link: https://bit.ly/2KeugYI

23. Premoli M, Bonaccorso S, Ricciardi A, Zangani C, Schifano F (2019) Cannabidiol: Recent advances and new insights for neuropsychiatric disorders treatment. Life Sci 224: 120-127. Link: https://bit.ly/3IFurtY

24. Silote GP, Sartim A, Sales A, Eskelund A, Guimarães FS, et al. (2019) Emerging evidence for the antidepressant effect of cannabidiol and the underlying molecular mechanisms. J Chem Neuroanatom 98: 104 -116. Link: https://bit.ly/3kJbfdu

25. Laczkovics C, Kothgassner OD, Felnhofer A, Klier CM (2020) Cannabidio treatment in an adolescent with multiple substance abuse, social anxiety and depression. Neuropsychiatry. Link: https://bit.ly/3nAoBuu

26. Navarrete F, García-Gutiérrez MS, Jurado-Barba R, Rubio G, Gasparyan A, et al. (2020) Endocannabinoid System Components as Potential Biomarkers in Psychiatry. Front Psychiatry. Link: https://bit.ly/35JUomQ

27. Pertwee RG (2004) The pharmacology and therapeutic potential of cannabidiol. In: Cannabinoids Di Marzo V. (Ed.), Kluwer Academic/Plenum Publishers 32-83.

28. Pertwee RG (2005) Cannabidiol as a potential medicine. In: Mechoulam R. (eds) Cannabinoids as Therapeutics. Milestones in Drug Therapy MDT. Birkhäuser Basel.

29. Schoedel KA, Szeto I, Setnik B, Sellers EM, Levy-Cooperman N, et al. (2018) Abuse potential assessment of cannabidiol (CBD) in recreational polydrug users: A randomized, double-blind, controlled trial. Epilepsy Behav 88: 162 171. Link: https://bit.ly/36JRv4y

Citation: Šulcová A (2020) Translational research of antidepressants with an example of cannabidiol effects. Arch Depress Anxiety 6(2): 062-065 
30. Viudez-Martinez A, García-Gutiérrez MS. Medrano-Relinque J, Navarrón CM, Navarrete F, et al. (2019) Cannabidiol does not display drug abuse potential in mice behavior. Acta Pharmacol Sin 40: 358-364. Link: https://bit.ly/36RPDH5

31. Elsaid S, kloiber S, Le foll B (2019) Effects of cannabidiol (CBD) in neuropsychiatric disorders: A review of pre-clinical and clinical findings. Prog Mol Biol Transl Sci 167: 25-75. Link: https://bit.ly/2ILtBgl

32. Hill MN, Carrier EJ, Mclaughlin RJ, Morrish AC, Meier SE, et al. (2008) Regional alterations in the endocannabinoid system in an animal model of depression: effects of concurrent antidepressant treatment. J Neurochem 106: 2322 2336. Link: https://bit.ly/3nDwiju

33. Hill MN, Hillard CJ, Bambico FR, Patel S, Gorzalka BB, et al. (2009) The Therapeutic Potential of the Endocannabinoid System for the Development of a Novel Class of Antidepressants. Trends Pharmacol Sci 30: 484-493. Link: https://bit.ly/38XDVgO

34. Bambico FR, Duranti A, Tontini A, Tarzia G, Gobbi G, et al. (2009) Endocannabinoids in the Treatment of Mood Disorders: Evidence from Animal Models. Current Pharmaceutical Design 15: 1623-1646. Link: https://bit.ly/2UCJjgP

35. Zanelati TV, Biojone C, Moreira FA, Guimaraes FS, Joca SR (2010) Antidepressant-like effects of cannabidiol in mice: Possible involvement of 5-HT 1 A receptors. Br J Pharmacol 159: 122-128. Link: https://bit.ly/3nIDATn

36. Réus GZ, Stringari RB, Ribeiro KF, Luft T, Abelaira HM, et al. (2011) Administration of cannabidiol and imipramine induces antidepressant-like effects in the forced swimming test and increases brain-derived neurotrophic factor levels in the rat amygdala. Acta Neuropsychiatrica 23: 241-248. Link: https://bit.ly/35KJc9n

37. Micale V, Di Marzo V, Šulcová A, Wotjak CT, Drago F (2013) Endocannabinoid system and mood disorders: priming a target for new therapies. Pharmacol Therap 138: 18-37. Link: https://bit.ly/2INutSa

38. de Mello Schier AR, de Oliveira Ribeiro NP, Coutinho DS, Machado S, Arias-Carrión O, et al. (2014) Antidepressant-like and anxiolytic-like effects of cannabidiol: CNS Neurol Dis Drug Targets 13: 953-960. Link: https://bit.ly/36SseFA

39. Campos AC, Fogaça MV, Sonego AB, Guimarães FS (2016) Cannabidiol, neuroprotection and neuropsychiatric disorders. Pharmacol Res 112: 119127. Link: https://bit.ly/396JmtZ

40. Corroon J, Phillips JA (2018) A Cross-Sectional Study of Cannabidiol Users Cannabis and Cannabinoid Research 3: 153-161. Link: https://bit.ly/3IVnNjD

41. Allen AP, Naughton M, Dowling J, Walsh A, Ismail F (2015) Serum BDNF as a peripheral biomarker of treatment-resistant depression and the rapid antidepressant response: A comparison of ketamine and ECT. J Affect Disord 186: 306-311. Link: https://bit.ly/2KgcUL3

42. Sales AJ, Fogaça MV, Sartim AG, Pereira VS, Wegener G, et al. (2019) Cannabidiol induces rapid and sustained antidepressant-like effects through increased BDNF signaling and synaptogenesis in the prefrontal cortex. Mol Neurobiol 56: 1070-1081. Link: https://bit.ly/35GzrZR

43. Noreen N, Muhammad F, Akhtar B, Azam F, Anwar MI (2018) Is Cannabidiol a Promising Substance for New Drug Development? A Review of its Potential Therapeutic Applications. Crit Rev Eukaryot Gene Expr 28: 73-86. Link: https://bit.ly/2ISX3kN

44. Perini G, Ramusino MC, Sinforiani E, Bernini S, Petrachi R (2019) A Cognitive impairment in depression: recent advances and novel treatments. Neuropsychiatr Dis Treat 15: 1249-1258.
45. Pinto JV, Saraf G, Frysch CH, Vigo D, Keramatian K, Trisha Chakrabarty T, et al. (2020) Cannabidiol as a Treatment for Mood Disorders: A Systematic Review. Can J Psychiatry 65: 213-227. Link: https://bit.ly/3IKmljD

46. Kasper S, Frazer A (2019) Editorial for Treatment-Resistant Depression (TRD). Int J Neuropsychopharmacol 22: 83-84. Link: https://bit.ly/3fd6Ga9

47. Baeken CH, Brem AK, Arns M, Brunoni AR, Filipčić I, et al. (2019) Repetitive transcranial magnetic stimulation treatment for depressive disorders: current knowledge and future directions. Curr Opin Psychiatry 32: 409-415. Link: https://bit.ly/32VdO6g

48. Willner P, Belzung C (2015) Treatment-resistant depression: are anima models of depression fit for purpose? Psychopharmacology 232: 3473-3495 Link: https://bit.ly/38U9Pum

49. Willner P, Gruca P, Lason M, Tota-glowczyk K, Litwa E, et al. (2019) Validation of chronic mild stress in the Wistar-Kyoto rat as an animal model of treatmentresistant depression. Behav Pharmacol 30: 239-250. Link: https://bit. ly/35H209o

50. Réus GZ, De Moura AB, Borba LA, Abelaira HM, Quevedo J (2019) Strategies for Treatment-Resistant Depression: Lessons Learned from Animal Models. Mol Neuropsychiatry 5: 178-189. Link: https://bit.ly/3klhi1Z

51. Papp M, Gruca P, Lason M, Tota-Glowczyk K, Niemczyk M, et al. (2018) Rapid antidepressant effects of deep brain stimulation of the pre-frontal cortex in an animal model of treatment-resistant depression. J Psychopharmacol 32 1133-1140. Link: https://bit.ly/2UGmEjW

52. Papp M, Gruca P, Faron-Górecka A, Kusmider M, Willner P (2019) Genomic Screening of Wistar and Wistar-Kyoto Rats Exposed to Chronic Mild Stress and Deep Brain Stimulation of PrefrontalCortex. Neuroscience 423: 66-75. Link: https://bit.ly/38V0wug

53. Xue SS, Xue F, Ma QR, Shi-Quan Wang SQ, Ying Wang Y, Qing-Rong Tan $\mathrm{QR}$, et al. (2019) Repetitive high-frequency transcranial magnetic stimulation reverses depressive-like behaviors and protein expression at hippocampa synapses in chronic unpredictable stress-treated rats by enhancing endocannabinoid signaling. Pharmacol Biochem Behav 184: 172738. Link: https://bit.ly/2UI1XDX

54. Shbiro I, Hen-Shoval D, Hazut N, Rapps K, Dar S, et al. (2019) Effects of cannabidiol in males and females in two different rat models of depression. Physiol Behav 201: 59-63. Link: https://bit.ly/38XjsZo

55. Barrett JE, Coyle JT, Williams M (2012) Translational Neuroscience: Applications in Psychiatry, Neurology, and Neurodevelopmental Disorders Cambridge University Press. Link: https://bit.ly/32U2do7

56. Gardner R, Mckinney WT (2001) Ethology and the Use of Animal Models. In Henn F., Sartorius N., Helmchen H., Lauter H. (eds) Contemporary Psychiatry. Springer, Berlin, Heidelberg. Link: https://bit.ly/2UHoFMI

57. Pistovčáková J, Šulcová Kelly J, Leonard B (2006) Behavioural and immune effects of cannabidiol in a mouse model of bilateral olfactory bulbectomy. International Journal of Neuropsychopharmacology 9: 778 . Link: https://bit.ly/2KiuKgt

58. Song C, Leonard BE (2005) The Olfactory Bulbectomised Rat as a Model of Depression. Neuroscience \& Biobehavioral Reviews 29: 627-647. Link: https://bit.ly/2UCDq3e

59. Zajkowska ZE, Evnglund A, Zunszain PA (2014) Towards a personalized treatment in depression: endocannabinoids, inflammation and stress response. Pharmacogenomics 15: 687-698. Link: https://bit.ly/2UDkpgX

Copyright: @ 2020 Šulcová A. This is an open-access article distributed under the terms of the Creative Commons Attribution License, which permits unrestricted use, distribution, and reproduction in any medium, provided the original author and source are credited.

Citation: Šulcová A (2020) Translational research of antidepressants with an example of cannabidiol effects. Arch Depress Anxiety 6(2): 062-065

DOI: https://dx.doi.org/10.17352/2455-5460.000054 